\title{
生命機能の分子認識と捕捉の高精密化に関する分析化学的研究
}

\author{
今井一洋
}

\section{Analytical Chemical Studies on High-Performance Recognition and Detection of Bio-molecules in Life}

\author{
Kazuhiro IMAI \\ Center for Research and Development, Kyoritsu College of Pharmacy, \\ 1-5-30 Shibakoen, Minato-ku, Tokyo 105-8512, Japan
}

(Received August 20, 2003)

\begin{abstract}
In order to understand the mechanism for maintaining life of animals based on the search of dynamics of biomolecules, I have developed several sensitive and selective methods for their quantification. Using the methods of derivatization with the developed benzofurazan fluorogenic reagents (4-fluoro-7-nitro-2,1,3-benzoxadiazole (NBD-F), ammonium 7-fluoro-2,1,3-benzoxadiazole 4-sulfonate (SBD-F) and etc.) followed by high-performance liquid chromatography (HPLC) - fluorescence detection, a certain kind of biological and clinical importances was demonstrated of chiral bio-molecules (D-amino acids, D-lactic acid and so on), peptides and proteins. The proposed method (derivatization with SBD-F, isolation of the fluorescent proteins by two-dimensional HPLC, enzymatic digestion and identification of the altered proteins by HPLC-mass spectrometry (MS) / MS with database-searching algorithm) for proteomics studies revieled the changed proteins in the islets of Langerhans of the dexamethazone-induced diabetic rats. An importance of catecholamine metabolism on the blood pressure regulation was also suggested by the method of HPLCchemiluminescence detection of catecholamines and their 3-O-methylmetabolites. A new field of Analytical Chemistry, i.e., Bio-Analytical Chemistry, was also proposed.
\end{abstract}

Key words_— benzofurazan reagent; chemiluminescence; HPLC; MS/MS; proteomics; bio-analytical chemistry

\section{はじめに}

分析化学の本質は物質の検出にある. 分析化学が 方法に関する学問であり，多くの自然科学に横断的 な方法について考える学問であるとすれば，物質の 検出法に関する問題は分析化学で最も真剣に取り上 げなければならない。一方で，検出の確実性はその 検出の量的再現性によって検証される。 ある研究者 が得た結果を，他者が追試して量的に同じ結果が得 られれば，その検出の妥当性が保証されるのであ る. 分析化学で取り扱う検出には，定量と言う概念 が絶えず付随しているものである.

ある物質が天然に純粋な形で存在することは極め て稀である．特に生命科学の分野では，多くは他の

共立薬科大学研究開発センター（†105-8512 港区芝公 園 1-5-30)

e-mail: imai-kz@ kyoritsu-ph.ac.jp

*本総説は, 平成 15 年度日本薬学会賞の受賞を記念し

て記述したものである.
物質と共存して存在している. したがって，その物 質の検出のためには他の類似物質との識別が必要と なる．物質の検出にはその物質の出す信号を捉える ことが多い. その物質の信号と共存物質の発する信 号（雑音）とを識別する必要がある，信号には種々 の種類があり，それを捉えるための方法も数多くあ る，例えば放射能を出す物質を検出するには，その 放射能を捉えればよい。非放射性の他の共存物質と 識別でき, 雑音ゼロの状態で高感度（信号/雑音比 が大きい）に検出できる．しかし，共存物質も放射 性物質であれば，信号と雑音とを識別できず，目的 物質を検出できない。 そこでそれらを除くか，分離 するか，あるいは目的物質を取り出す必要がある. すなわち，物質を分離する方法が必要である．分析 化学の取り扱う検出では, 分離を伴わない検出は稀 である，以上を概念図として示した（Fig. 1).

筆者は生命現象を分析化学的に捉えるにはどうし たらよいかを考えてきた，生命は生体が恒常性維持 


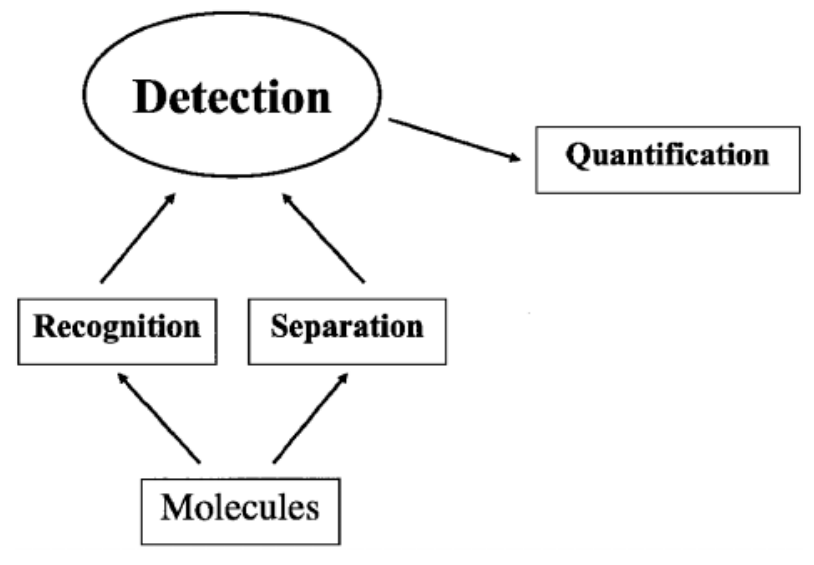

Fig. 1. Detection is the Heart of Analytical Chemistry!

機能を働かせることにより維持されている，筆者は この維持機能に関わる生体分子を検出し，その変動 を量的に捉えることにより生命現象を理解しようと 考えた．生体には無数の分子が存在している．しか も，平常状態の生体は維持機能を絶えず微妙に働か せて平衡状態を保っているため, 関連生体分子の変 動は微小であり，数多くの共存生体分子の中からそ の分子のみを捉えることは容易ではない．従来の物 質の検出法・分離法を十分利用するにしても，これ らのみに頼っていては研究が進まないことが分かっ た．そこで以下のような方策を考えた（Fig. 2). ${ }^{1-3}$ それは，生体の恒常性維持機能の及ぶ範囲内で生 体に連続的に負荷を懸けると，それに抵抗する生体 の反応が連続的に起こり，その結果として関連生体 分子が連続的に増量し，周囲から浮かび上がって見 えるようになる。そのような状態になれば関連生体 分子のみを捉えられるであろうというものである. すなわち，ここでは共存生体分子が雑音であり，関 連生体分子を信号と見なすと分かり易い。言うまで もなく，この生体分子を他の共存分子と分離して検 出・定量するのである.この手法を種々の恒常性維 持機能，例えば，血圧維持機能や血糖值維持機能に 適用すれば，生命現象の一端が理解できるであろ う。さらには, 生体恒常性維持機能の変質として理 解される病態，例えば高血圧や糖尿病と生体分子の 動態との関連把握，それらに基づく治療，ひいては 予防もできるのではないかと思われた。

本論文は, 生体分子の検出・分離・定量のための 方法の開発と生体試料への適用，及び前述した生体 恒常性維持機能の新しい側面からの研究について述

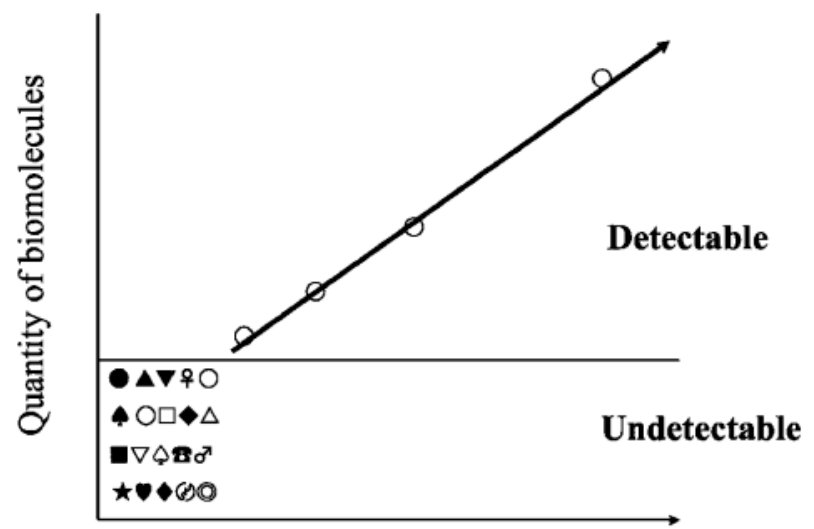

Stimulation to a living organism

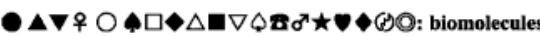

Fig. 2. The Way to Find the Related Molecule to Maintain the Life

ベたものである，検出法としては，信号に対し雑音 の少ないとされる光分析法（蛍光検出法，化学発光 検出法）を取り上げ，分離・定量法としては高性能 分離が期待される高速液体クロマトグラフィー （HPLC）を取り上げて検討した。

1. 蛍光試薬を用いる超高感度分離 · 検出 - 定量 法の開発と生体分子の捕捉

生体分子の多くは微量に存在し，かつ無蛍光であ る，そのため，それらを蛍光誘導体へと導き検出す るための蛍光誘導体化試薬が必要である. 1970 年 代後半当時, 微量の生体分子を定量するためのアミ ンの蛍光試薬としては，ダンシルクロライド，オル トフタルデヒドあるいはフルオレッサミンのみであ った。ダンシルクロライドは試薬の加水分解物が強 い蛍光を発するため扱いにくく，オルトフタルデヒ ドあるいはフルオレッサミンは第一級アミンとのみ しか蛍光誘導体を与えなかった，そこで新たな試薬 開発に取り組んだ。反応後得られる誘導体の蛍光波 長が生体分子の自然蛍光（400 nm 以下）より長波 長であること, 試薬自身無蛍光, 及び試薬の加水分 解物の蛍光が弱いと言う条件に適う蛍光試薬の創製 を目指し種々検討した。その結果，2,1,3-benzoxadiazole（ベンゾフラザン）骨格を有する 4-fluoro7-nitro-2,1,3-benzoxadiazole（NBD-F）をアミノ基 用蛍光誘導体化試薬として開発することができた (Fig. 3). ${ }^{4)} \mathrm{NBD}-\mathrm{F}$ は無蛍光で，各種アミン，アミ ノ酸，ペプチドと反応させて得た誘導体は蛍光波長 


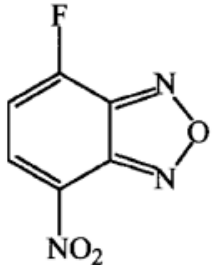

NBD-F

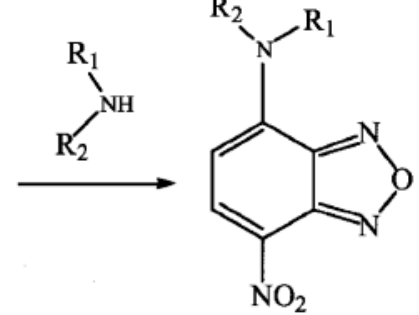

Em. $530 \mathrm{~nm} / \mathrm{Ex} .470 \mathrm{~nm}$
Fig. 3. NBD-F and Its Reaction with an Amine

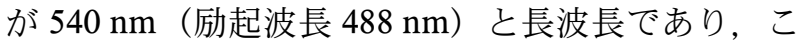
れらを HPLC で分離し蛍光検出するとサブピコモ

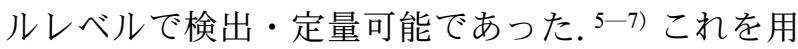
いて, タンパク質加水分解物中のアミノ酸, $\left.{ }^{8}\right)$ ヒト 血清中や新生坚濾紙血中のアミノ酸9-11) 分離定量 することができた。 その他のアミノ基含有分子，例

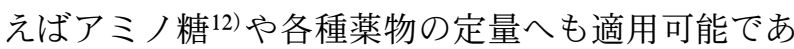
つた. ${ }^{13-15)} \mathrm{NBD}-\mathrm{F}$ はアミノ酸の内, トリプトファ ンとは反応するが蛍光体は与えない。これは光誘起 電子移動（Photoinduced Electrotransfer, PET）が 起こり，NBD 化トリプトファンの蛍光が消光され たためであった。そこで，トリプトファンのイン ドール骨格を光照射，又は電解酸化により破壊する

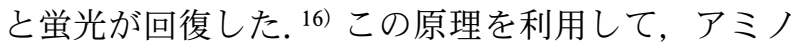
酸を NBD-F にて誘導体化後，これらを逆相 HPLC にて分離し，直列に接続したクーロメトリック検出 器を通してから蛍光検出すると，すべてのアミノ酸 が高感度に蛍光検出された. ${ }^{17)}$

NBD-F の加水分解物 (NBD-OH) は弱い蛍光 （励起波長 $380 \mathrm{~nm}$, 蛍光波長 $520 \mathrm{~nm}$ ）を与えるが, pH 3 以下で消光する. この現象を利用して NBD-F をアミノ酸分離後のポストカラム反応試薬に使うこ とができる. ${ }^{18)} \mathrm{NBD}-\mathrm{F}$ はフェノール性水酸基とも 反応するが，得られた誘導体は蛍光を有しない。し かし $380 \mathrm{~nm}$ の吸光度は大きい。これを利用して, チロシン含有ペプチドを NBD-F と反応させて得た 誘導体を単離抽出後, これに過剩のアミンを加え NBD 基をアミンに転移させ，チロシン含有ペプチ ドを回収することができる. ${ }^{19)}$

さらに，NBD 化したアミノ酸は HPLC 用パーク ル型キラル固定相により光学分割され, 高感度分離 定量できることが分かった。 ${ }^{20-24)}$ 従来，動物体内
における D-アミノ酸の存在についての情報は乏し かったが，この方法を用いることにより，ラット松 果体にD-アスパラギン酸が存在することを発見 し，その濃度が L- 体よりも多いことを見い出し た (Figs. 4, 5). ${ }^{25)}$ その濃度は夜間に高く, 加齢と ともに減少した。この知見を基にさらに研究を展開 し，D-アスパラギン酸の松果体内での存在意義や 生殖細胞でのステロイド合成への関与などを明らか にした。 ${ }^{26)}$ 腎障害患者のみならず健常人血漿にも Dアラニンや D- セリンが検出・定量できた. ${ }^{27,28)}$ さら に, 統合失調症患者の血漿中 D- セリン濃度が健常 人に比し減少していることを見出し，このことが当 該疾病診断への一助となることを示唆した. ${ }^{29)}$ 現在, D- アミノ酸の研究は生命科学領域における新しい 流れとして展開されている (3.の項目参照). ${ }^{30-48)}$

ついで， NBD-F の 7 位ニトロ基の代わりに，種 々の電子吸引性基を導入することにより反応性の異 なる発蛍光試薬を新規合成した（Fig. 6). ${ }^{49-51)}$ ま た，4位のフッ素の代わりにアミノアルキル基など を置換した各種官能基用ベンゾフラザン蛍光試薬 10 数種を新規に設計・合成した（Fig. 6). ${ }^{52-60)}$

$-\mathrm{SO}_{2} \mathrm{NH}_{2}$ を導入したチオール基用蛍光試薬 4Aminosulfonyl-7-fluoro-2,1,3-benzoxadiazole (ABD $-\mathrm{F})$, 49,61) 及び- $\mathrm{SO}_{3} \mathrm{H}$ を導入した Ammonium 7fluoro-2,1,3-benzoxadiazole 4-sulfonate ( SBD F) ${ }^{50,62)}$ を利用した蛍光検出 HPLC は，低分子のグ ルタチオンや，中分子ペプチドのインスリンなどの 高感度分離定量が可能となった. ${ }^{63-65)}$ 特に SBD-F を用いると，デキサメタゾン誘発糖尿病ラットのラ ンゲルハンス島中 II 型インスリン（䛚歯類には 2 種類のインスリンが存在する）が顕著に減少してい ることが判明し（Fig. 7, Table 1)，それが mRNA の減少に対応していることを明らかにすることがで きた（Fig. 8). ${ }^{66)}$ 㗉歯類の II 型インスリンとヒト インスリンとは類似しているため, 今後の糖尿病研 究に有用な知見と思われる.

一方，SBD-F は水溶性であるため，タンパク質 を誘導体化したときに水溶性を保つことができる. アルブミンなどのタンパク質も誘導体化後, HPLC 一蛍光検出法を用いて高感度分離定量が可能となっ た。この蛍光を基に，目的タンパク質を HPLCに て抽出し，これを酵素水解して SBD 化ペプチドと し，HPLC-蛍光検出及び HPLC-mass spectrometry 
$\mathrm{OA}-2500(\mathrm{R}) \mathrm{O}_{0}^{\mathrm{O}}$
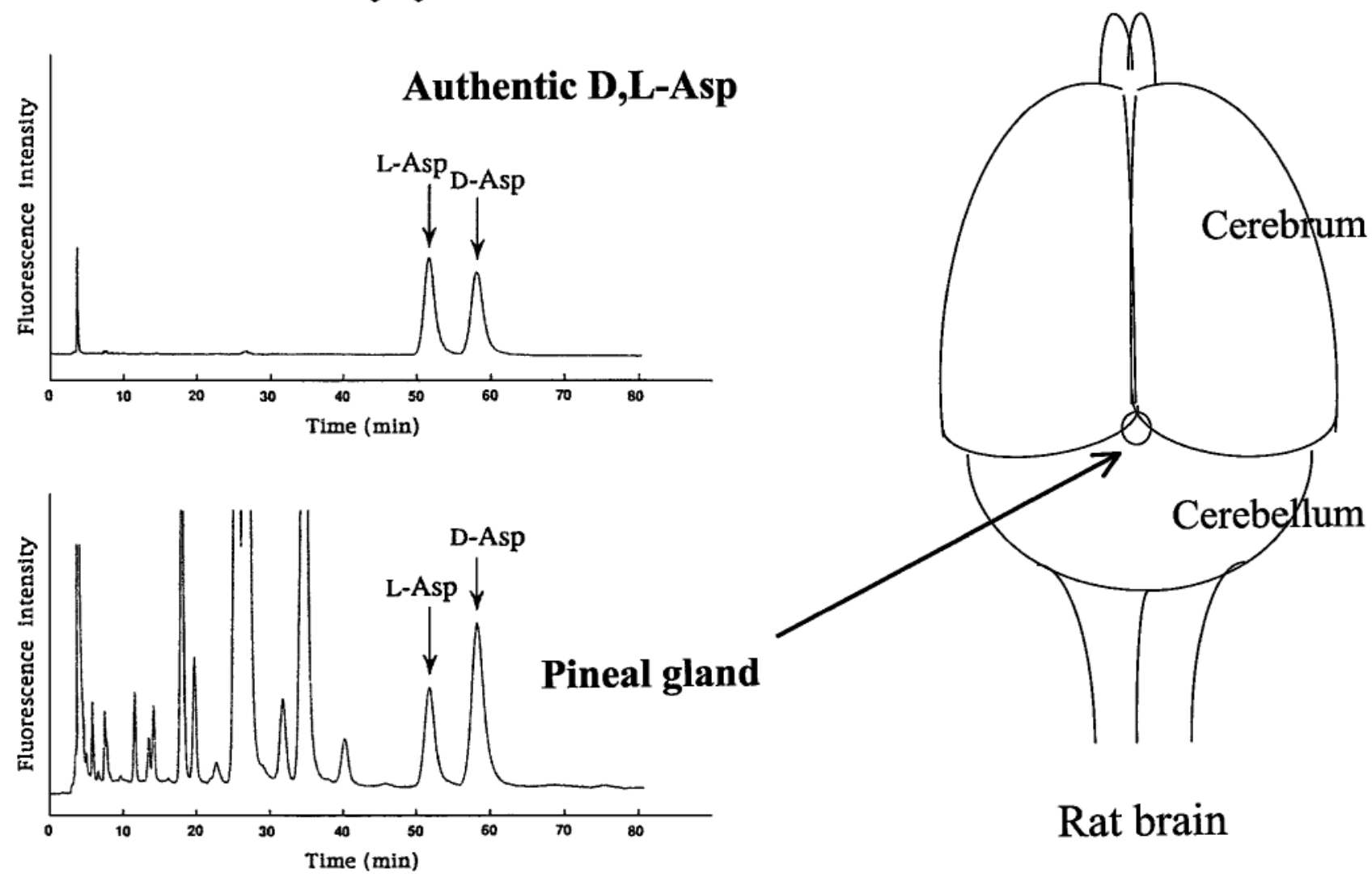

Rat brain

Fig. 4. D-Aspartic Acid Found in Rat Pineal Gland

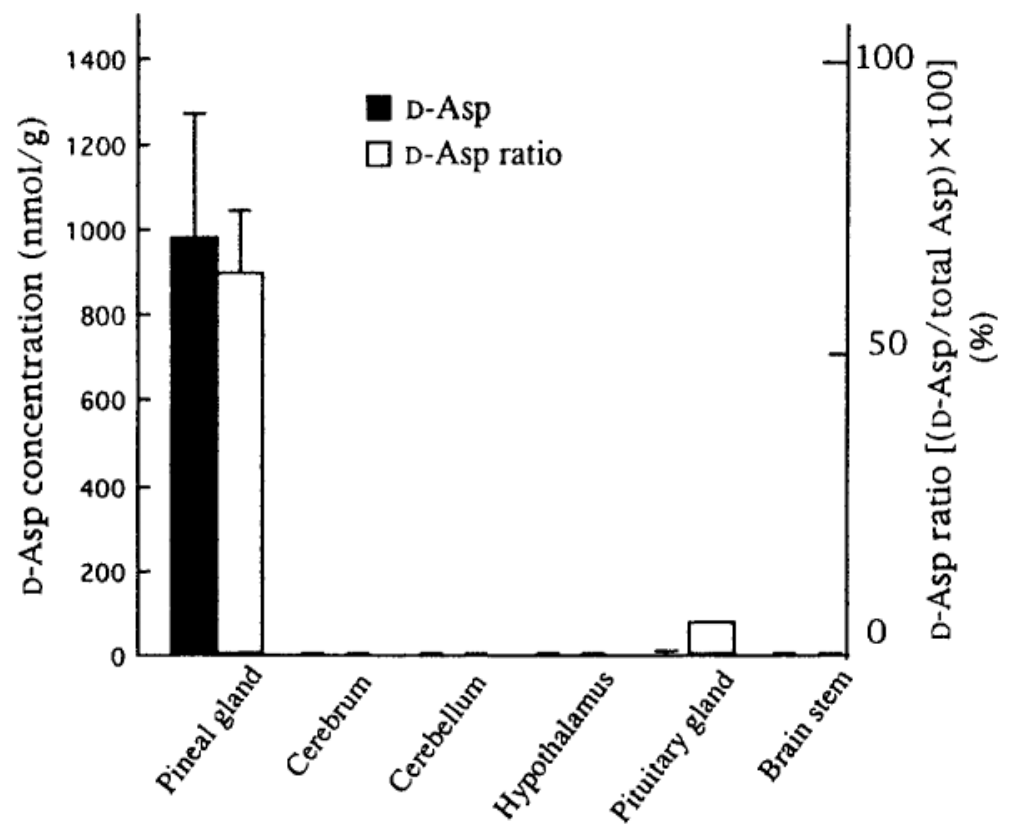

Fig. 5. Concentration of $\mathrm{D}-$ Aspartic Acid in Rat Brain 
<smiles>O=[N+]([O-])c1ccc(F)c2nonc12</smiles>

NBD-F<smiles></smiles>

DBD-COCl<smiles></smiles><smiles>COc1ccc(N(C)CCN)c2nc[nH]c12</smiles>

DBD-COHz<smiles>COc1ccc(F)c2nocc12</smiles>

DBD-F<smiles></smiles>

ABD-NCS<smiles>O=[N+]([O-])c1ccc(C2CNCN2)c2nonc12</smiles>

NBD-PZ<smiles>O=S(=O)(O)c1ccc(F)c2c1=NCC=2</smiles>

ABD-F<smiles>Nc1ccc(N(N)N)c2nc[nH]c12</smiles>
NBD-H<smiles>O=S(=O)(O)c1ccc(N2CCNC2)c2c1=NCC=2</smiles>

DBD-PZ<smiles></smiles>

SBD-F<smiles>COc1ccc(NN)c2nc[nH]c12</smiles>

DBD-H<smiles>O=[N+]([O-])c1ccc(F)c2nocc12</smiles>

CBD-F<smiles>NNc1ccc(OS(N)(=O)=O)c2nonc12</smiles>

ABD-H

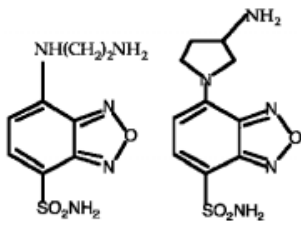

ABD-AE ABD-APy

Fig. 6. Fluorogenic Reagents Having Benzofurazan Structure

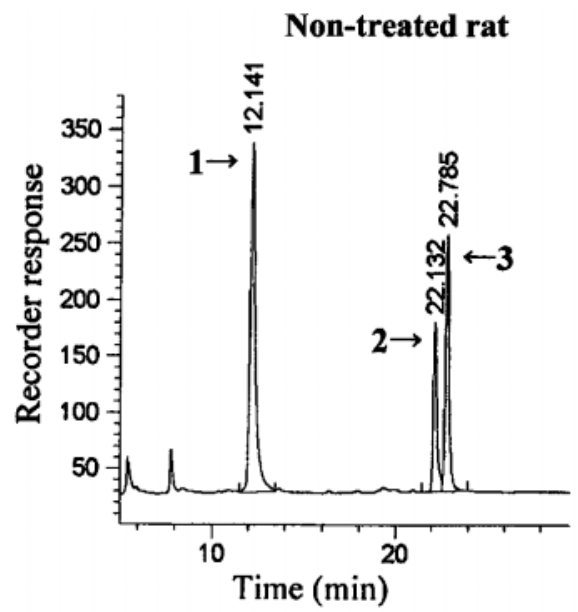

Dexamethazone-induced diabetic rat

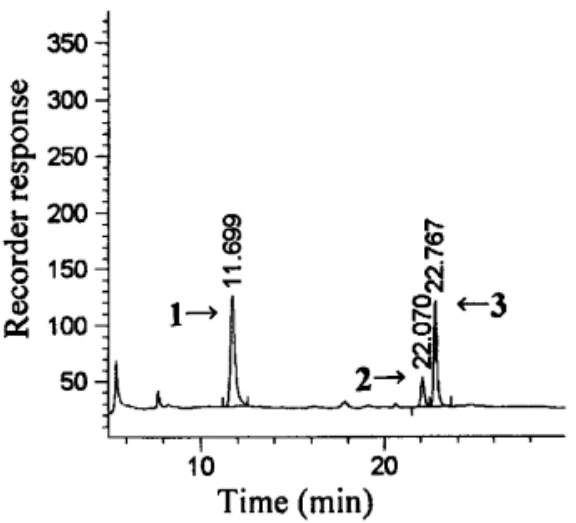

1. Chain A derivative

2. Chain B2 derivative

3. Chain B1 derivative

Fig. 7. Separative Determination of SBD-Insulin Isomers in a Single Islet of Rat Langerhans with or without Dexamethazone Treatment

(MS) / MS に付し目的タンパク質を同定すると言 う，新しいプロテオーム解析法を提唱した（Fig. 9). ${ }^{67)}$ 本解析法を用いて，デキサメタゾン誘発糖尿 病ラットのランゲルハンス島中タンパク質の変動を 調べると，数種のタンパク質の量的変動が明らかと なった (Table 2)。これらの変動の意義については 今後の検討課題である.

$\mathrm{ABD}$ 誘導体と SBD 誘導体が同一の励起，蛍光波
長を有すること，並びに ABD-F は脂溶性であるが, SBD-F は水溶性であると言う異なる特徵を利用し て，まず還元型チオールを ABD-F で誘導体化後, 非還元型チオールを還元剤の存在下 SBD-F で誘導 体化して，両者を同時に HPLC-蛍光検出する方法 を開発した。 ${ }^{68)}$ 本法により実験的膵臓ガン組織中の グルタチオン濃度の顕著な増加が明らかとなっ た. ${ }^{69)} \mathrm{A}$ 及び C 型肝炎発症マウス肝臓中グルタチオ 
Table 1. Contents of the Isomeric Insulins in the Islets of Rat Langerhans with or without Dexamethasone Treatment

\begin{tabular}{lcccc}
\hline \hline \multirow{2}{*}{ Treatment } & \multicolumn{3}{c}{ Insulin contents $(\mathrm{ng} /$ islet $)$} & Insulin 1/Insulin 2 \\
\cline { 2 - 4 } & Insulin 1 & Insulin 2 & Total & $1.5 \pm 0.1$ \\
Control & $86.7 \pm 10.8$ & $58.9 \pm 7.7$ & $145.5 \pm 17.0$ & $1.5 \pm 0.0$ \\
Vehicle & $108.2 \pm 12.8^{* *}$ & $72.7 \pm 8.0^{*}$ & $180.8 \pm 20.7^{* *}$ & $3.6 \pm 0.2^{* * *}$ \\
Dexamethasone & $55.8 \pm 4.4^{* * *}$ & $15.3 \pm 1.4^{* * *}$ & $71.1 \pm 5.6^{* * *}$ & $3.1 \pm 0$. \\
\hline
\end{tabular}

The results are expressed as mean $\pm \mathrm{SD}$ ( $n=5$ in each group).

Statistical significance versus control: $* p<0.05,{ }^{*} p<0.01$

Statistical significance versus vehicle: ${ }^{* * *} p<0.001$

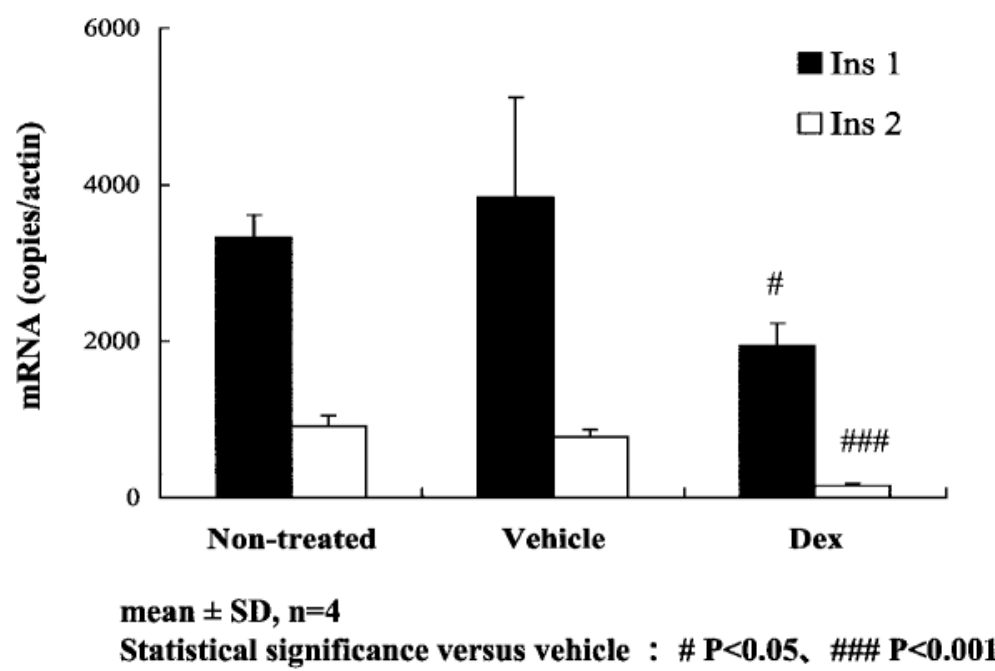

Fig. 8. Expressions of mRNAs for Insulins I and II in the Islets of Rat Langerhans with or without Dexamethasone Treatment

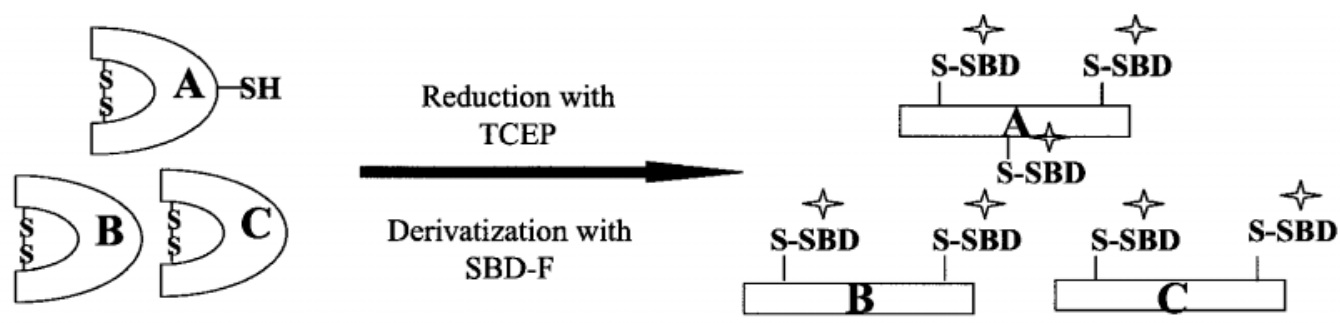

Proteins mixture

Fluorescent proteins

from the tissue

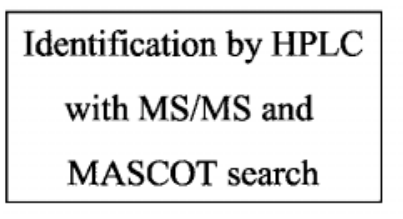

with MS/MS and

MASCOT search

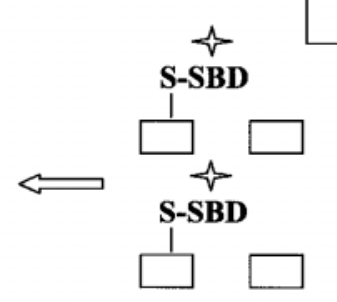

Peptides mixture

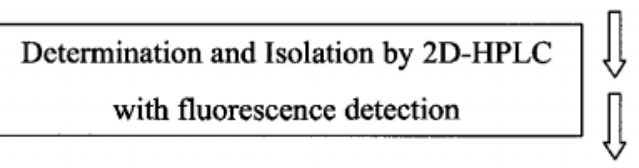

Digestion with trypsin

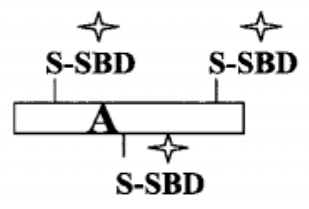

Altered proteins

(Proteins increased by stimulation)

Fig. 9. A Schematic Diagram for a New Method for Proteomics 
Table 2. The Altered Proteins in the Islets of Rat Langerhans with Dexamethazone Treatment for Two Days

\begin{tabular}{rclcc}
\hline \hline Peak no. & $\begin{array}{c}\text { Average ratio } \\
\text { (Dex/Control) }\end{array}$ & \multicolumn{1}{c}{ Protein } & Mw & $\begin{array}{c}\text { Database } \\
\text { accession no. }\end{array}$ \\
\hline 12 & 0.5 & Protein P31 & 13284 & CSRT31 \\
15 & 0.4 & dnaK-type molecular chaperone hsp 72-ps1 & 70884 & S31716 \\
24 & 2.1 & Pancreatic polypeptide & 10968 & NP_036758 \\
29 & 0.5 & Insulin 2 & 5797 & NP_062003 \\
30 & 6.0 & Proinsulin 2 & 12331 & NP_062003 \\
36 & 1.9 & 78 KD glucose-regulated protein & 72302 & P06761 \\
61 & 1.8 & Phosphatidylethanolammine binding protein & 20788 & NP_058932 \\
121 & 1.8 & Thioredoxin & 12854 & NP_446252 \\
\hline
\end{tabular}

ン定量にも使われた. ${ }^{70)}$

ABD-F はタンパク質の立体障害の少ない表面に 存在するチオール基とは容易に反応するが，立体障 害の大きいタンパク質内部のチオール基とは反応す ることが困難である。そこで緩和な条件下で反応さ せるとBSAの表面チオール基が，界面活性化剂存 在下に反応させると埋没チオール基とが反応するた め，両者を識別して検出できることが分かつた. ${ }^{71)}$ 緩和な条件下 $\mathrm{ABD}-\mathrm{F}$ をミオシンと反応させると， ミオシンの ATP 水解酵素活性部位近傍に ABD 化 されるので, このミオシンを使うと, ATP の水解 とともにアクチンとミオシンとの接近の様子を分光 学的に理解することが可能である. ${ }^{72)}$ 同様の手法は 他のタンパク質同士の相互作用解析に利用されてい る. ${ }^{73)}$

誘導体の吸着を押さえるべく $-\mathrm{SO}_{2} \mathrm{NH} \Phi \mathrm{SO}_{3} \mathrm{H}$ 基 を導入した水溶性アミノ基用蛍光試薬 3- (7-fluoro2,1,3-benzoxadiazole-4-sulfonamide) benzenesulfonic acid (m-BS-ABD-F) は, ブラジキニンやアンジ オテンシン類の高感度分離定量に適することが分か つた. ${ }^{74,75)}$ 一方, -NCS を導入した 7- N,N-dimethylaminosulphonyl-4- ( 2,1,3-benzoxadiazolyl) isothiocyanate (DBD-NCS), 及び 7-methylthio-4- (2,1,3benzoxadiazolyl) isothiocyanate (MTBD-NCS) は, D- アミノ酸含有蛋白のアミノ酸の絶対配置を保持 したままの配列解析法に適用でき, ${ }^{76-92)}$ アミロイ ド蛋白などの自然ラセミ化アミノ酸含有タンパク質 の解析に用いられることが期待されている.

ピペラジノ基導入のカルボキシル基用蛍光試薬で ある 4-N,N-dimethylaminosulfonyl-7-piperazino-2, 1,3-benzoxadiazole（DBD-PZ）により乳酸を蛍光 誘導体としたのち, D, L- 乳酸を光学分割高感度定
量する方法を開発した. ${ }^{93-95)}$ これによりラット血 漿中に D, L- 乳酸が存在すること, 糖尿病時での D体の上昇を明らかにした. ${ }^{96,97)} \mathrm{DBD}-\mathrm{PZ}$ は, ビタミ ン $\mathrm{E}$ 代謝物であるナトリウム利尿因子 $2,7,8$ trimethyl-2- ( $\beta$-carboxyethyl)-6-hydroxy chroman (LLU- $\alpha)$ と反応し蛍光誘導体を与える. これを用 いて LLU- $\alpha$ の高感度光学分割定量が可能となつ た. ${ }^{98-100)}$ 生体内で $S$-LLU- $\alpha$ が生成すること, $S$ - 体 は $R$ - 体よりも速やかに血墏中から尿中へ排泄され ることを明らかにした。 ${ }^{100)}$ 最近，高食塩負荷ラッ トのナトリウム排泄に LLU- $\alpha$ が関与することも見 出している.

また, 酸クロライド基を導入した水酸基用蛍光試 薬 4- ( $N$-chloroformylmethy- $N$-methyl) amino-7- $N, N$ dimethylaminosulfonyl-2,1,3-benzoxadiazole (DBD$\mathrm{COCl})^{101,102)}$ を用いて, 内因性カンナビノイド受容 体アゴニストであるアナンダミドの HPLC-蛍光検 出法を開発した。これを用いて微量のアナンダミド がラット脳内に存在することを明らかにした. ${ }^{103,104)}$

さらに，経験則や分子軌道理論を導入することに より,より合理的な試薬の開発を試みた（Fig. 10)。すなわち， 4, 7 位置換ベンゾフラザン化合物 の蛍光強度が, 置換基の Hammett 定数, あるいは 分子軌道法により算出した電子密度と 4,7 位軸方 向の双極子モーメントから予測できることを明らか にした. ${ }^{105)} 1$ 置換ベンゾフラザン化合物の蛍光量子 収率の予測も可能となつた. ${ }^{106,107)}$ また, 半経験的 分子軌道法 CAS/CI 法を適用することで, 蛍光量 子収率の予測を可能とし, カルボキシル基用蛍光 試薬 4-mercapto-7-methylthio-2,1,3-benzoxadiazole （MTBD-SH）や水溶性試薬を創製するに到つた (Fig. 11). 108-112) また，PET 現象を利用した新規発 
<smiles>O=[N+]([O-])c1ccc([N+](=O)[O-])c2nonc12</smiles>

PSBD-NCO<smiles>NC(=O)c1ccc([N+](=O)[O-])c2nonc12</smiles>

EPB<smiles>COc1ccc(S)c2nsnc12</smiles><smiles>Sc1ccc(S)c2nonc12</smiles>

MTBD-SH<smiles></smiles>

MTBD-NCS

AABD-SH<smiles>O=[N+]([O-])c1ccc(NCCP(c2ccccc2)c2ccccc2)c2nonc12</smiles>

NBD-DPP<smiles>COc1ccc(C(c2ccccc2)c2ccccc2)c2nonc12</smiles>

AABD-DPP

Fig. 10. Benzofurazan Reagents Synthesized Based on the Theoretical Calculation<smiles></smiles>

AcABD-F<smiles>NCCN1CCN(c2ccc([N+](=O)[O-])c3nonc23)CC1</smiles>

NBD-PZ- $\mathrm{NH}_{2}$<smiles>CCNc1ccc([N+](=O)[O-])c2nonc12</smiles>

ES-ABD-ED

Fig. 11. Water Soluble Reagents Designed for Liquid Chromatography/Mass Spectrometry

蛍光試薬も設計・合成している. ${ }^{113-115)}$ この流れに 沿つた試薬デザインは, ベンゾフラザン骨格の酸素 原子をセレン又は硫黄に置換した，ベンゾセレナジ アゾール（BSeD） 又はベンゾチアジアゾール (BThD) 骨格を有する蛍光試薬の開発をする場合 にも適用可能と思われる (Fig. 12). 116)

2. 化学発光検出高速液体クロマトグラフィーの

\section{開発}

蛍光検出 HPLC では, 迷光やラマン光による雑 音のために，検出の高感度化（高い信号/雑音比） に限界がある. 化学発光は化学反応で電子を励起状 態へ励起するので, 光源由来の雑音がなく, 信号/ 雑音比を上げることができる，そこで，シュウ酸エ<smiles>c1ccc2n[se]nc2c1</smiles><smiles>c1ccc2nsnc2c1</smiles>

\section{benzoselenadiazole benzothiadiazole}

Fig. 12. Structure of Benzoselenadiazole and Benzothiadiazole

ステルと過酸化水素により蛍光物質が発光する系 （過シュウ酸エステル化学発光反応）を取り上げ検 討した（Fig. 13）。本反応では，蛍光物質の酸化電 位が低い程励起され易く発光効率が高いことを見出 し, 本化学発光が CIEEL (Chemically Induced 


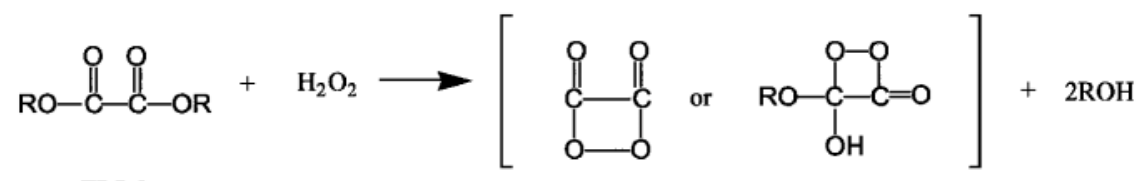

TDPO

D

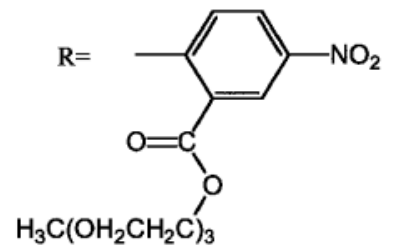

D $+\mathrm{Flu} \longrightarrow \mathrm{Flu}^{*}+2 \mathrm{CO}_{2}$

Flu* $^{*}$ Flu + hv

Fig. 13. A Mechanism for Peroxyoxalate Chemiluminescence Reaction

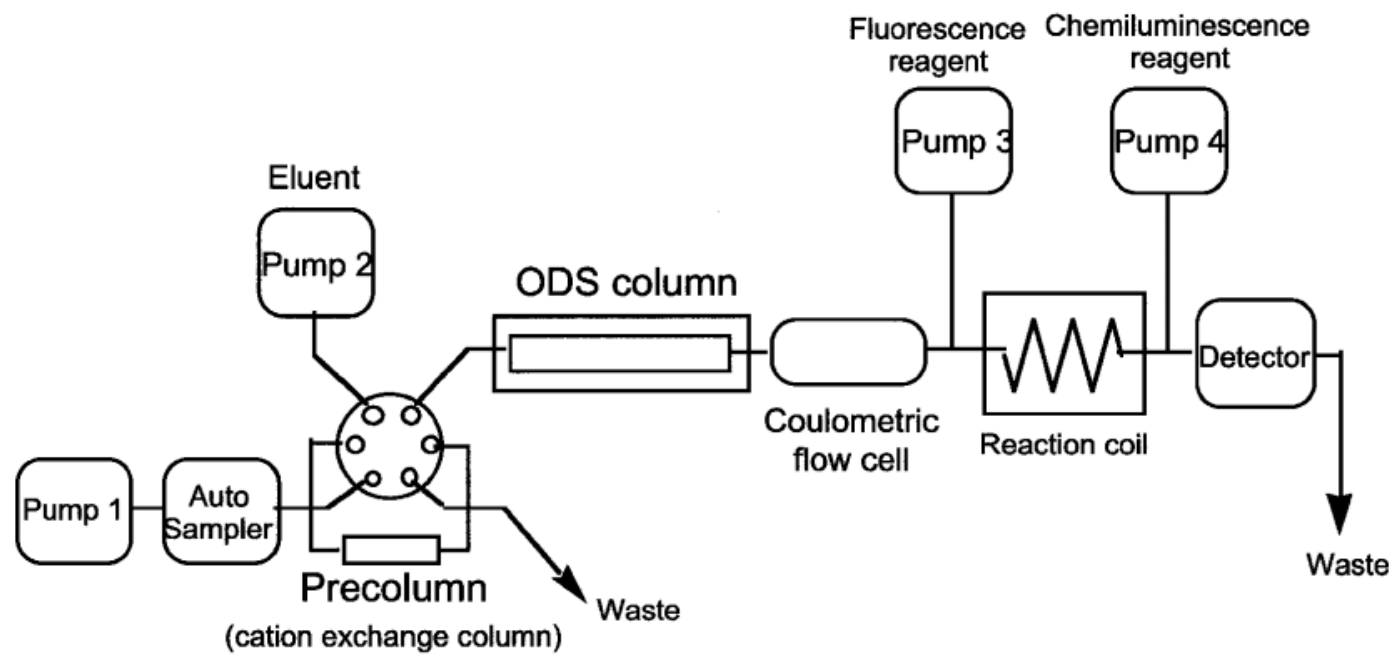

Fig. 14. A Flow Diagram for the Analyzer of Catecholamines and Their 3-O-Methyl Metabolites

Electron Exchange Luminescence) メカニズムに基

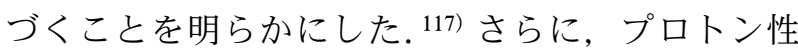
溶媒に溶け易いTDPO などの発光試薬も新規に開 発した. ${ }^{118)} こ の$ 化学発光反応系を世界で初めて HPLC の検出系に導入した. ${ }^{19,120)}$ 蛍光物質やシュ ウ酸エステルの種類，反応条件を精査した結果，本 定量法により，蛍光検出を用いる方法の 100 倍の高 感度化（フェムトモルからアトモルレベルの検出） が達成された. ${ }^{121-151)} こ の$ 化学発光 HPLC は, こ れまで感度的に不可能であった超微量薬物や有害化 学物質の追跡を可能とした. ${ }^{152-155)}$

さらに，カテコールアミン及び $O$ - メチル化代謝 物の分離，蛍光体へのオンライン縮合反応を組み込 んだ全自動分析計の開発へと発展させた（Fig. 14). ${ }^{156-160)}$ 本システムは超高感度であり，わずか 1 滴（約 $20 \mu \mathrm{l} ）$ の血液で血中カテコールアミン及
び $O$-メチル化代謝物の定量を可能とした（3. 参 照)。161,162) 本法は，種々疾患におけるカテコールア ミンの代謝動態を検討する上で有用である.

3. 恒常性維持機能解明へのアプローチ

既述した手法（信号を雑音より大きくして信号を 捕捉できるようにする方法）（Fig. 2）を用いて恒 常性維持機能が理解できるかどうかを検討した。 ットの血圧調節に関して得られた知見について記 す。163-167) 血圧を降圧薬で人為的に徐々に下げる と，圧受容体反射により交感神経が興奮し，血管を 収縮させるべく神経末端よりノルエピネフリン （NE）が徐々に放出される。薬理学的常識では，こ のように放出された NE は神経末端に再吸収される と言われるが，このような実験での NE の放出量は 通常レベルよりも極端に多くなるため，再吸収を免 れ血中に多量に放出される。これが全身を巡るの 
で，血中 NE 值は血圧の下降とともに通常レベルを 超えて増加するため捕捉が容易と考えられる．NE の定量は全自動カテコールアミン定量法により行っ た。測定值の対数を横軸に取り，血圧を縦軸に取り プロットすると両者は直線関係を示し，直線は右肩 下がりを示すことが分かった（Fig. 15).163) 得られ た直線の勾配は，血圧降下に対する個体の圧受容体 反射を介する交感神経機能を表している，勾配が急 であれば機能は鈍く，緩やかであれば機能は鋭敏で ある.このように，生体分子の変動を捕捉すること によって血圧の恒常性維持機能を理解できたのは初 めてである. 本相関関係は 1 匹のラットを用い，数 点の採血で定量を行い証明できた。開発した HPLC-化学発光検出法が超高感度であることを示 している。同様の実験を高血圧自然発症ラット (SHR) と正常血圧 (WKY) ラットとで行い，比較検 討してみた.その結果 SHR では機能が鈍いことを 初めて明らかにすることができた (Fig. 16).165,166,168)

一方で，過剰に血中に放出された NE は全身を巡 り，受容体に働き血圧を上げる要因となるはずであ る．SHR の血圧が高いのは，通常状態において も，放出されて血中を巡る NE が過剰に存在し受容 体に働き血圧を上げているのではないかと思われ た。生体は，ほぼ全身に存在する代謝酵素 catechol一 $O$-methyltransferase (COMT) により NE をメチル 化し，不活性なノルメタネフリン（NMN）へと変 換する。 そこで血中の放出 $\mathrm{NE}$ と NMN を同時に検 出・定量して, NEの増量に対して生成する NMN の割合を知れば，SHR における代謝能力が知れる と思われた，すなわち，先の全自動カテコールアミ ン定量法にて両者を同時に定量して，横軸にNEを 縦軸に NMN をプロットすると，右肩上がりの直 線が得られるはずである。勾配が緩やかであれば NE の代謝能力が低く，急であれば代謝能力が高い と考えられる。実際確かにそのような右肩上がりの 直線関係が得られ（Fig. 17），しかも，SHR では WKY に比べその勾配が緩やかであり，COMTに よる NE の NMN へのメチル化代謝活性が WKY ラ

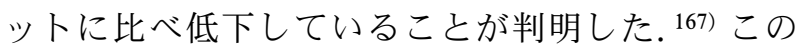
代謝活性低下が原因で SHR では通常の血圧が高い のではないかと思われた。

COMT は全身に分布し, しかも可溶性 COMT (S -COMT) と膜結合性 COMT (MB-COMT) が存在す

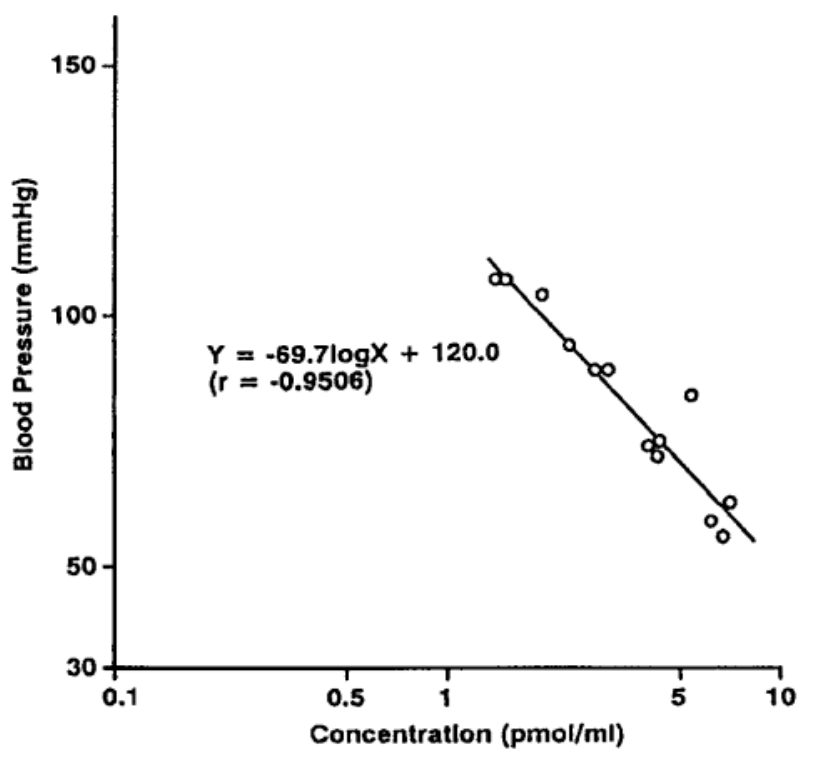

Fig. 15. A Relation between the Blood Pressure Reduction and Plasma Norepinephrine Concentration

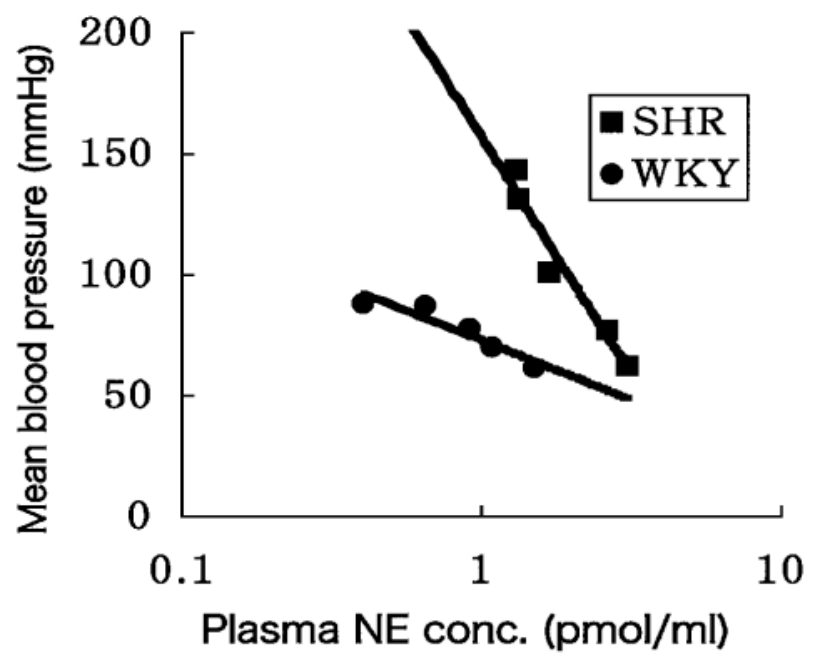

Fig. 16. A Relationship between the Blood Pressure Reduction and Plasma Norepinephrine (NE) Concentration in Spontaneous Hypertensive Rats and Wister-Kyoto Rats

ることが分かっている，そこで，どの器官のどちら の COMT が個体全体の COMT 活性を代表してい るのかを調べて見ようと考えた．ところが従来の測 定法は 3,4-dihydroxybenzoic acidのような人工基 質が使われていたため，それを利用しても生理的レ ベルの酵素活性を知ることは困難であると思われ た。むろ，生理的分子である $\mathrm{NE}$ を基質とした酵 素活性測定法を用いなければならない。この測定に は先に述ベた全自動カテコールアミン分析計を利用 


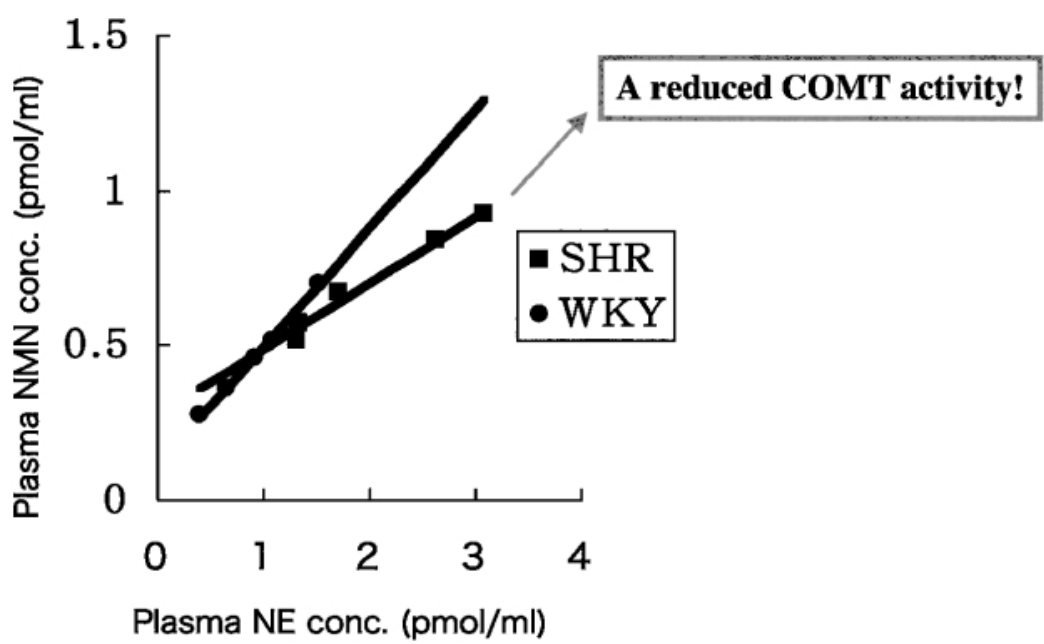

Fig. 17. A Relation between Plasma Norepinephrine (NE) and Normetanephrine (NMN) Concentration Induced by Blood Pressure Reduction in SHR and WKY Rats

することができた. ${ }^{169,170)}$ それを利用して COMT 活 性の高いとされる肝, 腎, 赤血球中の S-COMT 及 びMB-COMT の活性を調べてみた (Table 3)。そ の結果，肝 MB-COMT 活性值のみが，WKY との 比較において低いことが判明した。ささら抗体を用 いる定量法により肝 COMT 量の低下も証明され た。このことから判断して, 肝 MB-COMT 量の低 下が個体全体の COMT 活性低下を招来していると 思われた，以上の知見は，血圧調節への代謝酵素の 関与を示唆するものである．今後は遺伝子レベルの 検索が必要であるが，MB-COMT も S-COMT も 同一遺伝子配列より転写，翻訳されるため，生成に 至るまでに種々の因子の関与が想定される。これら の詳細な検討により, SHR と WKY の差が初めて 明らかになると思われる。

一方で, COMT の活性化により SHR の血圧低下 がもたらされると考えられた。ところが COMT 活 性化剤は知られていなかった。COMT の補酵素は $S$-adenosyl-L-methionine ( SAMe ) であり，もし COMT が血圧調節に関与しているならば，SAMe 投与により NE のメチル化が進行し，NEが減少す るので血圧は下降するはずである。実際，補酵素 $\mathrm{SAMe}$ の投与により COMT の活性化を行ったとこ ろ血圧は降下した. ${ }^{167)}$ 同時に定量した血中 NE 值は 減少し，NMN 值は上昇していることが判明してい る. 最近，この動物実験結果を基に臨床医との共同 研究が開始され，高血圧患者では運動負荷時の血中 NMN 量が低く，メチル化代謝活性低下が示唆され
Table 3. COMT Activities in Liver, Kidney and Red Blood Cells of SHR and WKY Rats

\begin{tabular}{llcc}
\hline \hline & \multicolumn{1}{c}{ Tissue } & SHR & WKY rats \\
\hline S-COMT & Liver & $3600 \pm 110^{* *}$ & $2180 \pm 290$ \\
& Kidney & $3740 \pm 680^{* *}$ & $1790 \pm 170$ \\
& Erythrocyte & $36.9 \pm 1.6$ & $24.2 \pm 3.2$ \\
MB-COMT & Liver & $114 \pm 10^{*}$ & $164 \pm 14$ \\
& Kidney & $84.3 \pm 3.2$ & $78.3 \pm 8.3$ \\
& Erythrocyte & $8.95 \pm 2.80$ & $4.62 \pm 0.55$ \\
\hline
\end{tabular}

The values represent the mean $\pm \mathrm{SD}$ ( $\mathrm{pmol} / \mathrm{min} / \mathrm{mg}$ protein), $n=8$.

*: $p<0.05, * *: p<0.01$ vs. WKY rats

ている. ${ }^{171)}$

この実験中に，血中アミノ酸の変動を調べたとこ ろ，SHR において，血圧降下とともに 10 数種のア ミノ酸のうちアルギニンのみが有意に減少している

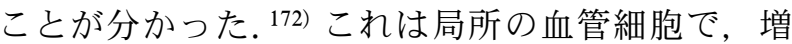
量 NE の作用に対抗するためアルギニンを基質とし て酸化窒素生成酵素により酸化窒素が急遽生成され るが，SHR では細胞内アルギニン不足を補うため の腎などから供給されるアルギニンが不足するの で，血中アルギニンが減少したと思われる。このこ とはSHR における腎機能に異常があることを示唆 している。ささらなる検討が必要である.

以上のように，生体に連続的に負荷を懸けると， それに抵抗する生体の反応が連続的に起こり，その 結果として関連生体分子が連続的に増量し，周囲か ら浮かび上がって見えるようになる。このようにし て関連生体分子を捉え生体恒常性維持機能の仕組み 
を明らかにしていけば，関連する病態の理解と治療 にも貢献できるのではないかと考えている．このよ うな一連の分析化学の研究領域を生命分析化学 (Bio-Analytical Chemistry) として提唱してい る. ${ }^{1-3,173)}$ 本論文がこの領域の展開にとつて 1 つの 刺激剂になれば幸いである。

\section{謝辞本論文は，筆者が東京大学薬学部並びに} 医学部付属病院分院に在職中に, 下記の方々と行っ た共同研究の成果を維めたものである．研究遂行に 当たり種々の御協力を戴き大変感謝しております. ここに御礼申し上げる次第です。（敬称略）

王 美代 都築浩雄 厚井芳則 田中 博 矢澤幸 平 堀川力三 荒川義弘 豊岡利正 宮野博 宇 津園子 遠藤宏一 植田英治 本田一匡 宮口公寿 森 啓太郎 神田 進 福島 健 萩原健一 三田智 文本間浩角田誠 Pablo Prados 浜瀬健司 村山一久 丸山若重 加藤 大 古賀大輔 合田竜 弥 木元克輔 酒井<夕子 隆 志群 李 仁愛 森 毅 吉岡大地 大谷 真 滝川有紀 鳥羽 陽 足立 伸也 市原秀晃 内山聖一 永田芳子 三橋和人 荒井美子 竹澤和子 竹田明美 松本 恵 東 健太 郎 沖山夏子 中田章仁 服部晃広 岡本泰三 是 永卓識 青山のぞみ 小野田真紀 菊田健太郎 和 田麗子 岡部弘基 鈴木祥子 沼沢祥行 長谷川久 紀 増田真由美 青山千顕 内野絵里香 塚本雄貴 平山靖晃 杉浦元孝 深谷順子 木谷行一 等々力 徹 小林伸一郎渡辺芳彦関野順松永浩和 飯田孝之 黄 永 葉 巷青 白尾美佳 榊原達哉 Guo Xingjie 上代才中島由紀 鳥海千冬 黄 承志 江口欣也 庄子房次

森 尚子 西谷篤彦 土屋雅勇 木津純子 仲村 祐子 黒川陽介 渡辺茂和 塚本幸恵 関根祐子 杉浦方紀 安野伸浩

新井洋由（東大薬）福山透（東大薬）長尾 拓 (東大薬) 岩坪 威（東大薬）嶋田一夫（東大薬）赤 羽悟美（東大薬）森屋恭爾（東大医）真重文子（東 大医）渡辺訓行（東大工）中島憲一郎（長崎大薬） 黒田直敬（長崎大薬）和田光弘（長崎大薬）早川和 一（金沢大薬）前田昌子（昭和大薬）松本宏次郎 (東邦大薬）西川 隆（北里大医）千田正昭（日本分 光）東 館栄（日本分光）阿部皓一（エーザイ）吉 村寛幸（エーザイ）中島基雄（キッコーマン）村上
成治（キッコーマン）河崎孝男（三共）川原幸則 （三共）高萩英邦（三共）成田 寛（田辺製薬）吉川 正美 (田辺製薬) 葛西千恵子（山之内製薬）小林 智（協和発酵）長島 健（協和発酵）片山圭士（協 和発酵) 横洲博親（東京化成）小方 博（和光純薬） 渡辺秀夫（東ソー）

又，本研究に御援助を賜りました，文科省 ヒ ユーマンサイエンス振興財団 東京生化学研究会 応用酵素研究財団 武田科学振興財団 薬理研究 会, 及び以下に記載の企業（株式会社）, 味の素 アトー 協和精密 キョーリン製薬 協和発酵 キ リンビール 三共 大日本製薬 武田薬品 山之内 製薬 吉富製薬 信和化工 住化分析センター 相 馬光学 ダイセル化学 東京化成 同仁化学 東 ソー 日本化学発光 日本分光 日立製作所 和光 純薬 に深謝いたします。

最後になりましたが, 私が研究者として歩むに当 たり多大なる御指導を賜りました恩師の田村善藏東 京大学名誉教授 南原利夫東北大学名誉教授 中嶋 暉躬東京大学名誉教授 Sidney Udenfriend 博士に 厚く御礼申し上げます。また, 時宜折々に適切な御 助言を賜りました 永津俊治 吉植庄平 岡田正志 秋山修三 辻章夫岩永貞昭 大菅俊明 タケル . ヒグチ 柴田承二 高木敬次郎 水野傳一 野島庄 七 坪井正道 粕谷豊 山田正篤 飯高洋一 福 田英臣 花野学 大野雅二 大澤利昭 清水博 宇井理生 荒田洋治 三川 潮 廣部雅昭 斉藤 洋 古賀憲司 名取俊二 井上圭三 首藤紘一 Benito del Castillo Willy Bayens Chang Kee Lim の諸先 輩，教授の先生方に心より感謝申し上げます.

\section{REFERENCES}

1) Imai K., Anal. Sci., 14, 257-264 (1998) .

2) Imai K., The Special Issue for the 8th Annual Meeting of Japanese Society of Pharmacist, 1998, pp. 13-21.

3) Imai K., Bunseki, 12, 718-722 (2000).

4) Imai K., Watanabe Y., Anal. Chim. Acta, 130, 377-383 (1981).

5) Toyo'oka T., Watanabe Y., Imai K., Anal. Chim. Acta, 149, 305-312 (1983).

6) Miyano H., Toyo'oka T., Imai K., Anal. Chim. Acta, 170, 81-87 (1985).

7) Miyano H., Toyo'oka T., Imai K., Nakajima 
T., Anal. Biochem., 150, 125-130 (1985).

8) Watanabe Y., Imai K., J. Chromatogr., 239, 723-732 (1982).

9) Watanabe Y., Imai K., Anal. Biochem., 116, 471-472 (1981).

10) Watanabe Y., Imai K., J. Chromatogr., 309, 279-286 (1984).

11) Kotaniguchi H., Kawakatsu M., Toyo'oka T., Imai K., J. Chromatogr., 420, 141-145 (1987).

12) Honda S., Okeda J., Iwanaga H., Kawakami S., Taga A., Suzuki S., Imai K., Anal. Biochem ., 286, 99-111 (2000).

13) Toyo'oka T., Suzuki T., Saito Y., Uzu U., Imai K., Analyst, 114, 1233-1240 (1989).

14) Imai K., Uzu S., Kanda S., Baeyens W. R. G., Anal. Chim. Acta, 290, 3-20 (1994).

15) Uchiyama S., Santa T., Okiyama N., Fukushima T., Imai K., Biomed. Chromatogr., 15, 295-318 (2001).

16) Imai K., Ueda E., Toyo'oka T., Anal. Chim. Acta, 205, 7-14 (1988).

17) Watanabe N., Toyo'oka T., Imai K., Biomed. Chromatogr., 2, 99-103 (1987).

18) Watanabe Y., Imai K., Anal. Chem., 55, 1786 -1791 (1983).

19) Toyo'oka T., Mantani T., Kato M., Biomed. Chromatogr., 17, 133-142 (2003).

20) Imai K., Fukushima T., Uzu S., Biomed. Chromatogr., 7, 177-178 (1993).

21) Imai K., Fukushima T., Biomed. Chromatogr., 7, 275-276 (1993).

22) Fukushima T., Kato M., Santa T., Imai K., Biomed. Chromatogr., 9, 10-17 (1995).

23) Kato M., Fukushima T., Santa T., Nakashima K., Nishioka R., Imai K., Analyst, 123, 28772882 (1998).

24) Kato M., Fukushima T., Shimba N., Shimada I., Kawakami Y., Imai K., Biomed. Chromatogr., 15, 227-234 (2001).

25) Imai K., Fukushima T., Hagiwara K., Santa T., Biomed. Chromatogr., 9, 106-109 (1995).

26) Nagata Y., Homma H., Matsumoto M., Imai K., FEBS Lett., 454, 317-320 (1999).

27) Fukushima T., Santa T., Homma H., Nagatomo R., Imai K., Biol. Pharm. Bull., 18, 11301132 (1995).

28) Okubo S., Mashige F., Hashimoto Y., Nakahara K., Kanazawa H., Matsushima Y., Fukushima T., Huang Y., Imai K., Chro- matogr., 21, 43-47 (2000).

29) Hashimoto K., Fukushima T., Shimizu E., Komatsu N., Watanabe H., Shinoda N., Nakazato M., Kumakiri C., Okada S., Hasegawa H., Imai K., Iyo M., Arch. Gen. Psychiatry, 60, 572-576 (2003).

30) Imai K., Fukushima T., Santa T., Homma H., Hamase K., Sakai K., Kato M., Biomed. Chromatogr., 10, 303-312 (1996).

31) Lee J. A., Homma H., Sakai K., Fukushima T., Santa T., Tashiro K., Iwatsubo Y., Yoshikawa M., Imai K., Biochem. Biophys. Res. Commun., 231, 505-508 (1997).

32) Imai K., Fukushima T., Santa T., Homma H., Sugihara J., Kodama K., Yoshikawa M., Proc. Jpn. Acad., 73, Ser. B 48-52 (1997).

33) Hamase K., Homma H., Takigawa Y., Fukushima T., Santa T., Imai K., Biochem. Biophys. Acta, 1334, 214-222 (1997).

34) Sakai K., Homma H., Lee J. A., Fukushima T., Santa T., Tashiro K., Iwatsubo T., Imai K., Biochem. Biophys. Res. Commun., 235, 433-436 (1997).

35) Huang Y., Nishikawa T., Satoh K., Iwata T., Fukushima T., Santa T., Homma H., Imai K., Biol. Pharm. Bull., 21, 156-162 (1998).

36) Sakai K., Homma H., Lee J. A., Fukushima T., Santa T., Tashiro K., Iwatsubo T., Imai K., Biochem. Biophys., 351, 96-105 (1998).

37) Fukushima T., Shirao M., Ichihara H., Santa T., Homma H., Imai K., Proc. Jpn. Acad., 74, Ser. B 18-23 (1998).

38) Takigawa Y., Homma H., Lee J. A., Fukushima T., Santa T., Iwatsubo T., Imai K., Biochem. Biophys. Res. Commun., 248, 641647 (1998).

39) Long Z., Homma H., Lee J. A., Fukushima T., Santa T., Iwatsubo T., Yamada R., Imai K., FEBS Lett., 434, 231-235 (1998).

40) Sakai K., Homma H., Lee J. A., Fukushima T., Santa T., Tashiro K., Iwatsubo T., Imai, K., Brain Res., 808, 65-71 (1998).

41) Imai K., Fukushima T., Santa T., Homma H., Huang Y., Shirao M., Miura K., Amino Acids, 15, 351-361 (1998).

42) Nagata Y., Homma H., Lee J. A., Imai K., FEBS Lett., 444, 160-164 (1999).

43) Nagata Y., Homma H., Matsumoto M., Imai K., FEBS Lett., 454, 317-320 (1999). 
44) Lee J. A., Homma H., Tashiro K., Iwatsubo T., Imai K., Brain Res., 838, 193-199 (1999).

45) Hamase K., Homma H., Takigawa Y., Imai K., Amino Acids, 17, 277-283 (1999).

46) Matsumoto M., Homma H., Long Z., Imai K., Iida T., Maruyama T., Aikawa Y., Endo I., Yohda M., J. Bacteriol., 181, 6560-6563 (1999).

47) Long Z., Lee J. A., Okamoto T., Nimura N., Imai K., Homma H., Biochem. Biophys. Res. Commun., 276, 1143-1147 (2000).

48) Lee J. A., Long Z., Nimura N., Iwatsubo T., Imai K., Homma H., Arch. Biochem. Biophys., 385, 242-249 (2001).

49) Toyo’oka T., Imai K., Anal. Chem., 56, 24612464 (1984).

50) Imai K., Toyo'oka T., Watanabe Y., Anal. Biochem., 128, 471-473 (1983).

51) Toyo'oka T., Suzuki T., Saito Y., Uzu S., Imai K., Analyst, 114, 413-419 (1989).

52) Uzu S., Kanda S., Imai K., Nakashima K., Akiyama S., Analyst, 115, 1477-1482 (1990).

53) Toyo'oka T., Ishibashi M., Takeda Y., Imai K., Analyst, 116, 609-613 (1991).

54) Toyo'oka T., Ishibashi M., Takeda Y., Nakashima K., Akiyama S., Uzu S., Imai K., J. Chromatogr., 588, 61-71 (1991) .

55) Toyo'oka T., Ishibashi M., Terao T., Imai K., Analyst, 118, 759-763 (1993).

56) Matsumoto K., Ichitani Y., Ogasawara N., Yuki H., Imai K., J. Chromatogr., 678, 241247 (1994).

57) Santa T., Kimoto K., Fukushima T., Homma H., Imai K., Biomed. Chromatogr., 10, 183185 (1996).

58) Prados P., Fukushima T., Santa T., Homma H., Tsunoda M., Kindy S. AL., Mori S., Yokosu H., Imai K., Anal. Chim. Acta, 344, 227-232 (1997).

59) Santa T., Luo J., Lim C. K., Imai K., Biomed. Chromatogr., 12, 73-77 (1998).

60) Santa T., Takeda A., Uchiyama S., Fukushima T., Homma H., Suzuki S., Yokosu H., Lim C. K., Imai K., J. Pharm. Biomed. Anal., 17, 1065-1070 (1998).

61) Toyo'oka T., Miyano H., Imai K., Biomed. Chromatogr., 1, 15-20 (1986).

62) Toyo'oka T., Imai K., Analyst, 109, 10031007 (1984).
63) Toyo’oka T., Imai K., Chromatogr., 282, 495 -500 (1983).

64) Toyo'oka T., Imai K., Kawahara Y., J. Pharm. Biomed. Anal., 2, 473-479 (1984).

65) Imai K., Aramaki Y., Anal. Sci., 2, 393-394 (1986).

66) Toriumi C., Imai K., Anal. Chem., 74, 23212327 (2002).

67) Toriumi C., Imai K., Anal. Chem., 75, 37253730 (2003).

68) Toyo'oka T., Uchiyama S., Saito Y., Imai K., Anal. Chim. Acta, 205, 29-41 (1988).

69) Toyo’oka T., Furukawa F., Suzuki T., Saito Y., Takahashi M., Hayashi Y., Uzu S., Imai K., Biomed. Chromatogr., 3, 166-172 (1989).

70) Moriya K., Nakagawa K., Santa T., Shintani Y., Fujie H., Miyoshi H., Tsutsumi T., Miyazawa T., Ishibashi K., Horie T., Imai K., Todoroki T., Kimura S., Koike K., Cancer Res., 61, 4365-4370 (2001).

71) Toyo’oka T., Imai K., Anal. Chem., 57, 19311937 (1985).

72) Hiratsuka T., J. Biol. Chem., 286, 2474224750 (1993).

73) Weber J., Bijol V., Wilke-Mounts S., Senior A. E., Arch. Biochem. Biophys., 397, 1-10 (2002).

74) Kajiro T., Fukushima T., Santa T., Imai K., Analyst, 125, 1115-1121 (2000).

75) Kajiro T., Fukushima T., Imai K., Anal. Biochem., 297, 52-59 (2001).

76) Toriba A., Adzuma K., Santa T., Imai K., Anal. Chem., 72, 732-739 (2000) .

77) Imai K., Uzu S., Nakashima K., Akiyama S., Biomed. Chromatogr., 7, 56-57 (1993).

78) Imai K., Matsunaga H., Fukushima T., Santa T., Homma H., Nakashima K., Akiyama S., Biomed. Chromatogr., 9, 152-154 (1995).

79) Imai K., Matsunaga H., Santa T., Homma H., Biomed. Chromatogr., 9, 195-196 (1995).

80) Matsunaga H., Santa T., Hagiwara K., Homma H., Imai K., Anal. Chem., 67, 4276-4282 (1995).

81) Matsunaga H., Iida T., Fukushima T., Santa T., Homma H., Imai K., Biomed. Chromatogr., 10, 95-96 (1996).

82) Matsunaga H., Santa T., Iida T., Fukushima T., Homma H., Imai K., Anal. Chem., 68, 2850-2856 (1996). 
83) Iida T., Matsunaga H., Fukushima T., Santa T., Homma H., Imai K., Anal. Chem., 69, 4463-4468 (1997).

84) Matsunaga H., Santa T., Iida T., Fukushima T., Homma H., Imai K., Analyst, 122, 931936 (1997).

85) Iida T., Matsunaga H., Santa T., Fukushima T., Homma H., Imai K., J. Chromatogr. A, 813, 267-275 (1998).

86) Iida T., Santa T., Toriba A., Imai K., Analyst, 123, 2829-2834 (1998).

87) Toriba A., Santa T., Iida T., Imai K., Analyst, 124, 43-48 (1999).

88) Huang Y., Matsunaga H., Toriba A., Santa T., Fukushima T., Imai K., Anal. Biochem., 270, 257-267 (1999).

89) Huang Y., Santa T., Uchiyama S., Imai K., Biomed. Chromatogr., 14, 133-136 (2000).

90) Toriba A., Adzuma K., Santa T., Imai K., Anal. Chem., 72, 4, 732-739 (2000).

91) Toriba A., Huang Y., Santa T., Imai K., Anal. Chim. Acta, 415, 57-66 (2000).

92) Okiyama N., Santa T., Toriba A., Imai K., Anal. Chim. Acta, 429, 293-300 (2001).

93) Ichihara H., Fukushima T., Imai K., Anal. Biochem., 269, 379-385 (1999).

94) Fukushima T., Adachi S., Ichihara H., AlKindy S. M., Imai K., Biomed. Chromatogr., 13, 418-424 (1999).

95) Fukushima T., Lee J. A., Korenaga T., Ichihara H., Kato M., Imai K., Biomed. Chromatogr., 15, 189-195 (2001).

96) Hattori A., Fukushima T., Yoshimura H., Abe K., Imai K., Biol. Pharm. Bull., 23, 13951397 (2000).

97) Fukushima T., Santa T., Homma H., AlKindy S. M., Imai K., Anal. Chem., 69, 17931799 (1997).

98) Hattori A., Fukushima T., Imai K., Anal. Biochem., 281, 209-215 (2000).

99) Hattori A., Fukushima T., Yoshimura H., Abe K., Imai K., Biol. Pharm. Bull., 23, 13951397 (2000).

100) Hattori A., Fukushim T., Hamamura K., Kato M., Imai K., Biomed. Chromatogr., 15, 95-99 (2001).

101) Imai K., Fukushima T., Yokosu H., Biomed. Chromatogr., 8, 107-113 (1994).

102) Yang X., Fukushima T., Santa T., Homma
H., Imai K., Analyst, 122, 1365-1369 (1997).

103) Arai Y., Fukushima T., Shirao M., Yang X., Imai K., Biomed. Chromatogr., 14, 118-124 (2000).

104) Koga D., Santa T., Hagiwara K., Imai K., Takizawa H., Nagano T., Hirobe M., Ogawa M., Sato T., Inoue K., Kudo I., Biomed. Chromatogr., 9, 56-57 (1995).

105) Uchiyama S., Santa T., Fukushima T., Homma H., Imai K., J. Chem. Soc., Perkin Trans., 2, 2165-2173 (1998).

106) Uchiyama S., Santa T., Imai K., J. Chem. Soc., Perkin Trans., 2, 2525-2532 (1999).

107) Uchiyama S., Santa T., Okiyama N., Azuma K., Imai K., J. Chem. Soc., Perkin Trans., 2, 1199-1207 (2000).

108) Uchiyama S., Santa T., Imai K., Anal. Chem., 73, 2165-2170 (2001).

109) Uchiyama S., Santa T., Imai K., J. Chem. Soc., Perkin Trans., 2, 569-576 (1999).

110) Uchiyama S., Santa T., Suzuki S., Yokosu H., Imai K., Anal. Chem., 71, 5367-5371 (1999).

111) Santa T., Okamoto T., Uchiyama S., Mitsuhashi K., Imai K., Analyst, 124, 1689-1693 (1999).

112) Uchiyama S., Santa T., Imai K., Anal. Chem., 73, 2165-2170 (2001)

113) Onoda M., Uchiyama S., Santa T., Imai K., Anal. Chem., 74, 4089-4096(2002).

114) Uchiyama S., Santa T., Imai K., Analyst, 125, 1839-1845 (2000).

115) Onoda M., Uchiyama S., Endo A., Tokuyama H., Santa T., Imai K., Org. Lett., 5, 14591461 (2003).

116) Triumi C., Santa T., Imai K., Proc. Jpn. Acad., 79, Ser. B, 137-140 (2003).

117) Honda K., Miyaguchi K., Imai K., Anal. Chim. Acta, 177, 111-120 (1985).

118) Imai K., Nawa H., Tanaka M., Ogata H., Analyst, 111, 209-211 (1986).

119) Kobayashi S., Imai K., Anal. Chem., 52, 424427 (1980).

120) Kobayashi S., Imai K., Anal. Chem., 52, 1548 -1549 (1980).

121) Honda K., Sekino J., Imai K., Anal. Chem., 55, 940-943 (1983).

122) Miyaguchi K., Honda K., Imai K., J. Chromatogr., 303, 173-176 (1984).

123) Kobayashi S., Sekino J., Honda H., Imai K., 
Anal. Biochem., 112, 99-104 (1981).

124) Miyaguchi K., Honda K., Imai K., J. Chromatogr., 316, 501-505 (1984).

125) Honda K., Miyaguchi K., Imai K., Anal. Chim. Acta, 177, 103-110 (1985).

126) Honda K., Miyaguchi K., Nishino H., Tanaka H., Yao T., Imai K., Anal. Biochem., 153, 5053 (1986).

127) Miyaguchi K., Honda K., Toyo’oka T., Imai K., J. Chromatogr., 352, 255-260 (1986).

128) Nozaki O., Ohba Y., Imai K., Anal. Chim. Acta, 205, 255-260 (1988).

129) Imaizumi N., Hayakawa K., Miyazaki M., Imai K., Analyst, 114, 161-164 (1989).

130) Imai K., Higashidate S., Tsukamoto Y., Uzu S., Kanda S., Anal. Chim. Acta, 225, 421-424 (1989).

131) Imai K., Higashidate S., Nishitani A., Tsukamoto Y., Ishibashi M., Shoda J., Osuga T., Anal. Chim. Acta, 227, 21-27 (1989).

132) Nakashima K., Maki K., Akiyama S., Wang W. H., Tsukamoto Y., Imai K., Analyst, 114, 1413-1416 (1989).

133) Nakashima K., Akiyama S., Tsukamoto Y., Imai K., Dyes and Pigments, 12, 21-26 (1990).

134) Imai K., Nishitani A., Tsukamoto Y., Wang W. H., Kanda S., Biomed. Chromatogr., 4, 100-104 (1990).

135) Baeyens W., Bruggeman J., Dewaele C., Lin B., Imai K., J. Biolum. Chemilum., 5, 13-23 (1990).

136) Nakashima K., Maki K., Akiyama S., Imai K., Biomed. Chromatogr., 4, 105-107 (1990).

137) Higashidate S., Hibi K., Senda M., Kanda S., Imai K., J. Chromatogr., 515, 577-584 (1990).

138) Nakashima K., Maki K., Kawaguchi S., Akiyama S., Tsukamoto Y., Imai K., Anal. Sci., 7, 709-713 (1991).

139) Nakashima K., Hayashida N., Kawaguchi S., Akiyama S., Tsukamoto Y., Imai K., Anal. Sci., 7, 715-718 (1991).

140) Nakashima K., Suetsugu K., Yoshida K., Imai K., Akiyama S., Anal. Sci., 7, 815-816 (1991).

141) Sugiura M., Kanda S., Imai K., Anal. Chim. Acta, 266, 225-231 (1992).

142) Sugiura M., Kanda S., Imai K., Biomed.
Chromatogr., 7, 149-154 (1993).

143) Nakashima K., Wada M., Kuroda N., Akiyama S., Imai K., J. Liq. Chromatogr., 17, 2111 -2126 (1994).

144) Prados P., Santa T., Homma H., Imai K., Anal. Sci., 11, 575-580 (1995).

145) Wada M., Nakashima K., Kuroda N., Akiyama S., Imai K., J. Chromatogr. B., 678, 129136 (1996).

146) Kimoto K., Gohda R., Murayama K., Santa T., Fukushima T., Homma H., Imai K., Biomed. Chromatogr., 10, 189-190 (1996).

147) Gohda R., Kimoto K., Santa T., Fukushima T., Homma H., Imai K., Anal. Sci., 12, 713719 (1996).

148) Imai K., Matsunaga Y., Tsukamoto Y., Nishitani A., J. Chromatogr., 400, 169-176 (1987).

149) Imai K., Tsukamoto Y., Nishitani A., Chromatogr., 24, 77-81 (1987).

150) Nishitani A., Tsukamoto Y., Kanda S., Imai K., Anal. Chim. Acta, 251, 247-253 (1991).

151) Uzu S., Imai K., Nakashima K., Akiyama S., Analyst, 116, 1353-1357 (1991).

152) Nishitani A., Kanda S., Imai K., Biomed. Chromatogr., 6, 124-127 (1992).

153) Nakashima K., Suetsugu K., Yoshida K., Akiyama S., Uzu S., Imai K., Biomed. Chromatogr., 6, 149-154 (1992).

154) Uzu S., Imai K., Nakashima K., Akiyama S., J. Pharm. Biomed. Anal., 10, 979-984 (1992).

155) Prados P., Higashidate S., Imai K., Sato Y., Nagao T., Biomed. Chromatogr., 8, 49-51 (1994).

156) Higashidate S., Imai K., Analyst, 117, 18631868 (1992).

157) Prados P., Higashidate S., Imai K., Biomed. Chromatogr., 8, 1-8 (1994).

158) Tsunoda M., Takezawa K., Santa T., Imai K., Anal. Biochem., 269, 386-392 (1999).

159) Murayama K., Santa T., Imai K., Chromatogr., 19, 207-215 (1998).

160) Takezawa K., Tsunoda M., Murayama K., Santa T., Imai K., Analyst, 125, 293-296 (2000).

161) Takezawa K., Tsunoda M., Watanabe N., Imai K., Anal. Chem., 72, 4009-4014 (2000).

162) Tsunoda M., Takezawa K., Yanagisawa T., 
Kato M., Imai K., Biomed. Chromatogr., 15, 41-44 (2001).

163) Higashidate S., Imai K., Prados P., AdachiAkahane S., Nagao T., Biomed. Chromatogr., 8, 19-21 (1994).

164) Imai K., Higashidate S., Prados P., Santa T., Adachi-Akahane S., Nagao T., Biol. Pharm. Bull., 17, 907-910 (1994).

165) Prados P., Santa T., Homma H., Doi H., Narita H., del Castillo B., Martin M.A., Imai K., Biol. Pharm. Bull., 20, 341-344 (1997) .

166) Prados P., Santa T., Fukushima T., Homma H., Kasai C., Martin M.A., del Castillo B., Imai K., Hypertens. Res., 21, 147-153 (1998).

167) Imai K., Tsunoda M., Takezawa K., Mitsuhashi K., Santa T., Nagashima K., Katayama K., Ohmori K., Proc. Jpn. Acad., 75, Ser. B, 224-227 (1999).
168) Tsunoda M., Takezawa K., Santa T., Ina Y., Nagashima K., Ohmori K., Kobayashi S., Imai K., Jpn. J. Pharmacol., 83, 39-45 (2000).

169) Tsunoda M., Takezawa K., Imai K., Analyst, 126, 637-640 (2001) .

170) Aoyama N., Tsunoda M., Nakagomi K., Imai K., Biomed. Chromatogr., 16, 255-260 (2002).

171) Masuda M., Tsunoda M., Yusa Y., Yamada S., Imai K., Ann. Clin. Biochem., 39, 589-594 (2002)

172) Prados P., Matsunaga H., Mori T., Santa T., Fukushima T., Homma H., Kasai C., Imai K., Biomed. Chromatogr., 13, 27-32 (1999).

173) Kajiro T., Nakajima Y., Fukushima T., Imai K., Anal. Chem., 74, 4519-4525 (2002). 